\title{
Granulomatosis with polyangiitis
}

\author{
INSERM
}

\section{Source}

INSERM. (1999). Orphanet: an online rare disease and orphan drug data base.

Granulomatosis with polyangiitis. ORPHA:900

A rare anti-neutrophil cytoplasmic antibodies (ANCA)-associated vasculitis characterized by necrotizing inflammation of small and medium vessels (capillaries, venules and arterioles), resulting in tissue ischemia. 